\title{
鉄系クラッド材の界面における拡散挙動
}

\author{
大道雅 幸 $1, * 1$ \\ 大谷博 司 ${ }^{1, * 4}$ \\ 里 昌 英 $1, * 2$ \\ 1九州工業大学工学部 \\ 2 福岡県工業技術センター
}

徳 永 辰 也 ${ }^{2, * 3}$

J. Japan Inst. Metals, Vol. 68, No. 12 (2004), pp. 1013-1019

Special Issue on Computer Aided Phase Diagram Assessment and Its Extension to Materials Design C 2004 The Japan Institute of Metals

\section{Diffusion Behavior at the Interface of Cladding Steels}

\author{
Masayuki Omichi ${ }^{1, * 1}$, Masahide Sato ${ }^{1, * 2}$, Tatsuya Tokunaga ${ }^{2, * 3}$, \\ Hiroshi Ohtani ${ }^{1, * 4}$ and Mitsuhiro Hasebe ${ }^{1, * 4}$ \\ ${ }^{1}$ Department of Materials Science and Engineering, Kyushu Institute of Technology, Kitakyushu 804-8550 \\ ${ }^{2}$ Fukuoka Industrial Technology Center, Kitakyushu 807-0831
}

\begin{abstract}
Various cladding materials consisting of plain carbon steels with lower carbon concentrations and alloy steels with higher carbon concentrations have been considered to analyze the behavior of interdiffusion across the interface theoretically. The combination of the plain carbon steel and the alloy steel for the cladding was selected to make the chemical potential of carbon greater in the plain carbon steel than in the alloy steel. For the selection, the phase diagrams were computed with Thermo-Calc. The theoretical analysis was carried out using DICTRA that is the software developed at the Royal Institute of Technology in Sweden. The analysis indicates that the up-hill diffusion of carbon spontaneously occurs from the plain carbon steel to the alloy steel during annealing at elevated temperatures. For example, the cladding material composed of a plain carbon steel with a concentration of 0.046 mass $\% \mathrm{C}$ and a $18 \mathrm{Cr}-8 \mathrm{Ni}$ stainless steel with a concentration of 0.06 mass $\% \mathrm{C}$ exhibits such an up-hill diffusion at 1200 $\mathrm{K}$, resulting in precipitation of $\mathrm{Cr}_{23} \mathrm{C}_{6}$ at the cladding interface.
\end{abstract}

(Received June 28, 2004; Accepted September 10, 2004)

Keywords: cladding steel, diffusion controlled transformations, up-hill diffusion

\section{1. 緒言}

地球環境問題に取り組みながら持続可能な工業生産を維持 していくことは，21 世紀におけるわが国の大きな課題であ る. 地球環境問題としては, 地球温暖化, オゾン層破壊, 酸 性雨，化石然料や鉱物資源の枯渴などが代表的であるが，こ の中でも特に地球温暖化は, その発生源や循環のメカニズム が十分に解明されていないために, 問題の解決が困難視され ている. 温暖化の原因の一つに $\mathrm{CO}_{2}$ などの温暖化ガスの発 生が挙げられているが, 鉄鋼材料の製造過程で発生するこれ らの温暖化ガス抑制の観点から, 鉄鋼のリサイクル技術の確

*1 九州工業大学大学院生 (Graduate Student, Kyushu Institute of Technology)

*2 九州工業大学学生, 現在 : ダイジェット工業秼 (Undergraduate Student, Kyushu Institute of Technology Present address: DIJET Industrial Co. LTD.)

*3 CREST-独科学技術振興機構 (Present address: Core Research for Evolutional Science and Technology(CREST), Japan Science and Technology Agency, Kitakyushu 804-8550, Japan)

*4 CREST-独科学技術振興機構 (Japan Science and Technology Agency)
立が重要である. 鉄鋼のスクラップの再生利用上最も深刻で あるのは, リサイクルの進行とともに除去不能な不純物元素 が混入し, 結果的に鋼材の品質を低下させる, いわゆるカス ケード化の問題である.これを回避するためには, 少ない資 源で必要十分な機能を確保し, 使用後は表面層の除去により 再利用が可能となる表面改質プロセスの開発が必要である.

表面改質技術としては, 異種の金属材料同士を張り合わせ たクラッド法がよく知られているが，この技術では接合界面 での拡散を阻止し, 母材の強度や表面層の耐食性, 耐磨耗性 など, もとの表面層が有している機能をそのまま利用するこ とが一般的である.しかしながら, クラッド化後に表面に新 たな機能を付加するためには, 界面における拡散を意識的に おこさせることが重要である。例えば， C 濃度の低い汎用鋼 と高い高級鋼を張り合わせ，熱処理を施すと， C 濃度の低い

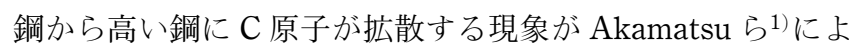
り見出されている．この知見を応用すれば，沉用の低級鋼の 表面に薄い高級鋼をクラッドし熱処理を施すことにより，表 層に炭化物を析出させて, 少ない資源で耐食性や耐磨耗性な ぞの機能を獲得することができる.しかも, どのような用途 にでも用いることが可能な沉用鉄鋼材料をクラッドの内側に 採用することで, スクラップ中への不純物蓄積を大幅に低減 
できる可能性がある. そこで本研究では, 低炭素普通鋼と高 炭素高級鋼とのクラッド材を取り上げ，その接合界面での拡 散挙動を熱力学, 動力学的計算手法を用いて解析することを 目的とした。

\section{2. 計 算 方 法}

\section{1 拡散律速型変態計算ソフトゥェア DICTRA の構成}

本研究では, クラッド鋼板の界面近傍での拡散挙動を解析 するために, スウェーデン王立工科大学において開発された 拡散律速型変態計算ソフトウェア DICTRA 2 をを用いた.

このソフトウェアの基本構成を Fig.1 に示した. データ ベースには, 動力学データと熱力学データが数值化されてい るが, 動力学データとしては, 実験值に基づいて評価された 元素の易動度の振動数因子と活性化エネルギーがパラメータ 化されている. 一方, 熱力学データは同じくスウェーデン王 立工科大学で開発された熱平衡計算ソフトウェア ThermoCalcのデータベースにリンクされており，これを用いて界 面での局所平衡を計算する. 拡散方程式の解と局所平衡計算 の結果より界面での流量バランスを決定し, さらにその時間 積分から異相界面の位置を求めることで, 拡散プロファイル の時間変化を決定している.

\section{2 拡散方程式}

DICTRA による計算の基本となる拡散方程式と界面移動 の計算方法について，その概要をまとめる ${ }^{3)}$. まず多元系に 抢ける元素の拡散は, Fickの法則により式(1)のように表 される.

$$
J_{k}=-\sum_{j=1}^{n} D_{k j} \frac{\partial c_{i}}{\partial z}
$$

ここで $J_{k}$ は元素 $k$ の流量で, 体積固定座標系4)で定義される. $D_{k j}$ は元素 $j$ の濃度勾配による元素 $k$ の相互拡散係数, $c_{j}\left[\mathrm{~mol} / \mathrm{m}^{3}\right]$ は元素 $j$ の濃度, $z$ は距離を表している. この式 に時間に関する連続条件である式 ( 2 )を組み合わせること で，濃度の時間変化を計算することができる.

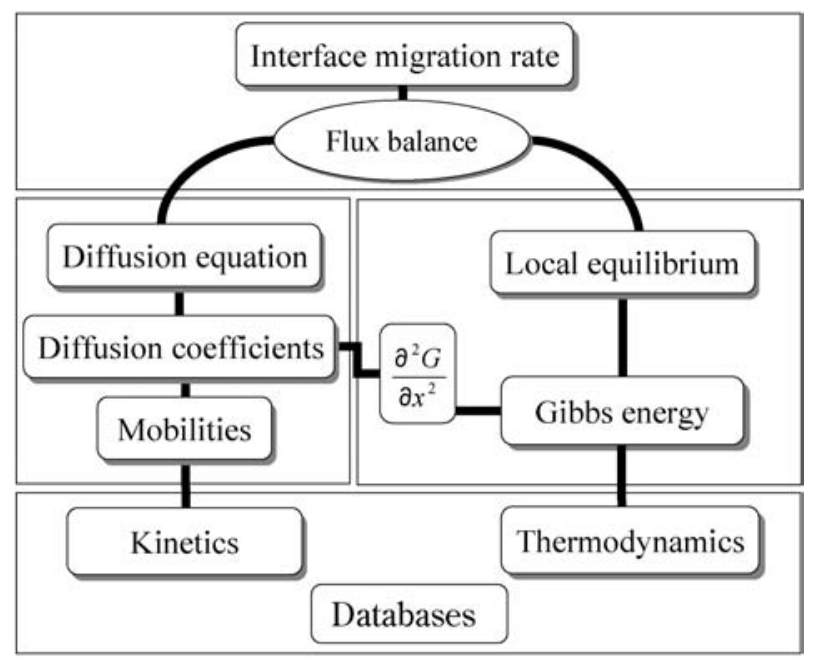

Fig. 1 General structure of the DICTRA software.

$$
\frac{\partial c}{\partial t}=-\operatorname{div}\left(J_{k}\right)
$$

一方, 元素 $i$ の化学ポテンシャル勾配を用いた場合の, 元素 $k$ の流量 $\tilde{J}_{k}$ は式 (3)で記述される. ただしこの式には, モル 数固定座標系が用いられている4).

$$
\tilde{J}_{k}=-\sum_{i=1}^{n} L_{k i} \frac{\partial \mu_{i}}{\partial z}
$$

$\mu_{i}$ は元素 $i$ のつ化学ポテンシャルで, $L_{k i}$ は拡散流量と全 元素の化学ポテンシャル勾配(拡散の駆動力)を結びつける現 象係数である. 拡散が結晶中に存在する空孔により支配され ているとすると, 式 ( 3 )の $L_{k i}$ の非対角成分はほぼ 0 と考え る仮定が成立するので5), 式( 3 )は式 (4)のように表される.

$$
\tilde{J}_{k}=-L_{k k} \frac{\partial \mu_{k}}{\partial z}
$$

ただし

$$
\begin{aligned}
& L_{k k}=c_{k} y_{V a} \Omega_{k V a} \\
& \Omega_{k V a}=\frac{M_{k}}{y_{V a}} \quad(k \text { が置換型元素の場合 }) \\
& \Omega_{k V a}=M_{k} \quad(k \text { が侵入型元素の場合 })
\end{aligned}
$$

式 ( 5 )において, $y_{V a}$ は元素 $k$ が存在する格子上での空孔濃 度, $M_{k}$ は元素 $k$ の易動度である. 式 $(3)$ を, 体積固定座標 系4)で書き直すと,

$$
J_{k}=-\sum_{i=1}^{n} L_{k i}^{\prime} \frac{\partial \mu_{i}}{\partial z}
$$

と表される.ただし $L_{k i}^{\prime}$ は

$$
L_{k i}^{\prime}=\sum_{j=1}^{n}\left(\delta_{j k}-c_{k} V_{j}\right) \cdot L_{j i}
$$

であり，式（５）を用いればさらに式（８）のように書き直さ れる。

$$
L_{k i}^{\prime}=\sum_{j=1}^{n}\left(\delta_{j k}-c_{k} V_{j}\right) \cdot c_{j} y_{V a} M_{j}
$$

ここで $\delta_{j k}$ はクロネッカーのデルタ $(j=k$ の時 1 , それ以外 は 0$), c_{k}$ および $c_{j}$ は単位体積あたりの元素 $k$ および $j$ の濃 度, $V_{j}$ は元素 $j$ の部分モル体積である.

さらに式( 6 )は式 ( 9 )のように書き直すことができる.

$$
J_{k}=-\sum_{i=1}^{n} L_{k i}^{\prime} \sum_{j=1}^{n} \frac{\partial \mu_{i}}{\partial c_{j}} \frac{\partial c_{j}}{\partial z}
$$

式 (1) と式 (9)を比較することにより， $D_{k j}$ と $L_{k i}^{\prime}$ は式 (10) のように関係付けられる.

$$
D_{k j}=\sum_{i=1}^{n} L_{k i}^{\prime} \frac{\partial \mu_{i}}{\partial c_{j}}
$$

このように, DICTRA にお打拡散係数 $D_{k j}$ は, $\partial \mu_{i} / \partial c_{j}$ で 表される熱力学因子と比例定数 $L_{k i}^{\prime}$ で表される動力学因子の 2 つから構成される.

実際の計算では, 式 (10) 中の $n$ 個の化学ポテンシャル勾 配は互いに関係し合う．全ての置換型成分が同じ部分モル体 積を持つと仮定し, 置換型成分にのみ体積を考慮した場合, 拡散係数は次のように表される.

$$
\begin{array}{ll}
D_{k j}^{n}=D_{k j}-D_{k n} & \text { (置換型の場合) } \\
D_{k j}^{n}=D_{k j} & \text { (侵入型の場合) }
\end{array}
$$

$D_{k j}^{n}$ は相互拡散係数, $n$ は従属成分である. したがって多元 系における拡散方程式は結局式(13)のようになる. 
Table 1 Kinetic parameters of Fe in FCC phase.

\begin{tabular}{|c|c|c|c|c|}
\hline \multirow{6}{*}{$\begin{array}{l}\text { Mobility } \\
\text { of Fe }\end{array}$} & $R T \ln M_{\mathrm{Fe}}^{\mathrm{Cr}}$ & $-82 T$ & $Q_{\mathrm{Fe}}^{\mathrm{Cr}}$ & 235000 \\
\hline & $R T \ln M_{\mathrm{Fe}}^{\mathrm{Fe}}$ & $R T \ln \left(7 \times 10^{-5}\right)$ & $Q_{\mathrm{Fe}}^{\mathrm{Fe}}$ & 258600 \\
\hline & $R T \ln M_{\mathrm{Fe}}^{\mathrm{Cr}: \mathrm{C}}$ & $-82 T$ & $Q_{\mathrm{Fe}}^{\mathrm{Cr} C \mathrm{C}}$ & 235000 \\
\hline & $R T \ln M_{\mathrm{Fe}}^{\mathrm{Fe} \mathrm{C}}$ & $R T \ln \left(7 \times 10^{-5}\right)$ & $Q_{\mathrm{Fe}}^{\mathrm{Fe}: \mathrm{C}}$ & 258600 \\
\hline & ${ }^{0} Q_{\mathrm{Fe}}^{\mathrm{Cr}, \mathrm{Fe}: \mathrm{Va}}$ & -15900 & ${ }^{0} Q_{\mathrm{Fe}}^{\mathrm{Cr}, \mathrm{Fe}: \mathrm{C}}$ & -15900 \\
\hline & ${ }^{0} Q_{\mathrm{Fe}}^{\mathrm{Cr} \text {, Fe:Va }}$ & -15900 & ${ }^{0} Q_{\mathrm{Fe}}^{\mathrm{Cr}, \mathrm{Fe}: \mathrm{C}}$ & -15900 \\
\hline
\end{tabular}

Activation energies are in $\mathrm{J} / \mathrm{mol}$ and frequency factors are in $\mathrm{m}^{2} / \mathrm{s}$.

$$
J_{k}=-\sum_{j=1}^{n-1} D_{k j}^{n} \frac{\partial c_{j}}{\partial z}
$$

\section{3 界面における流量バランス}

$n$ 元系において $\alpha$ から $\gamma$ への相変態を考えた場合, 界面に おける流量バランスの式桄は式(14)により表される.

$$
\frac{v}{V_{m}}\left[x_{k}^{\alpha}-x_{k}^{\gamma}\right]=J_{k}^{\alpha}-J_{k}^{\gamma} \quad(k=1,2 \cdots, n-1)
$$

ここで $v$ は界面移動速度, $V_{m}$ はモル体積 $(\alpha$ と $\gamma$ で等しいと 仮定)， $x_{k}^{\alpha}$ と $x_{k}^{\gamma}$ は， $\alpha, \gamma$ 相の境界近傍にお打る元素 $k$ の濃度，

$J_{k}^{\alpha}$ と $J_{k}^{\gamma}$ は拡散流量である。 $x_{k}^{\alpha}$ と $x_{k}^{\gamma}$ は, 界面に抢ける局所平 衡を仮定して Thermo-Calc を用いた平衡計算により求めら れる。

\section{4 動力学データ}

式 ( 8 ) に打晹動度 $M_{j}$ は, 振動数因子 $M_{j}^{o}$ と活性化工 ネルギー $Q_{j}$ の值を用いて式(15)のように表される.

$$
M_{j}=\frac{M_{j}^{o}}{R T} \exp \left(\frac{-Q_{j}}{R T}\right)
$$

式(15)を変形することにより，

$$
R T \ln \left[R T M_{j}\right]=R T \ln M_{j}^{o}-Q_{j}
$$

が得られるが， $R T \ln M_{j}^{o}$ や $Q_{j}$ の組成依存性は式(17)のよう に表される。

$$
\boldsymbol{\Phi}_{j}=\sum_{i} x_{i} \boldsymbol{\Phi}_{j}^{i}+\sum_{i} \sum_{k>i} x_{i} x_{k}\left[\sum_{r=0}^{m}{ }^{r} \boldsymbol{\Phi}_{j}^{i, k}\left(x_{i}-x_{k}\right)^{r}\right]
$$

$\Phi_{j}$ は式(16)中の $R T \ln M_{j}^{o}$ や $Q_{j}$ を表している. また $\Phi_{j}^{i}$ は元 素 $i$ 中の $\Phi_{j}$ の值, ${ }^{r} \boldsymbol{\Phi}_{j}^{i, k}$ は $i$ および $k$ 元素間の $\Phi_{j}$ の組成依存 である。すでに述べたように，DICTRA では動力学データ として $R T \ln M_{j}^{o}$ と $Q_{j}$ がパラメータ化されている．との一 例として， $\mathrm{Fe}-\mathrm{Cr}-\mathrm{C}$ 系の FCC 相に打ける $\mathrm{Fe}$ のパラメータ を Table 1 に示した ${ }^{7,8)}$.このパラメータを含め, 本研究で は DICTRA Ver. 22 に付属している MOB2(Mobility database version 1998-04-08)の動力学データを用いた.

\section{5 熱力学データ}

本研究で対象とした $\mathrm{Fe}-\mathrm{Si}-\mathrm{C}, \mathrm{Fe}-\mathrm{Cr}-\mathrm{C}, \mathrm{Fe}-\mathrm{Mn}-\mathrm{Si}-\mathrm{Al}-\mathrm{C}$, $\mathrm{Fe}-\mathrm{Cr}-\mathrm{Ni}-\mathrm{C}, \mathrm{Fe}-\mathrm{Cr}-\mathrm{Ni}-\mathrm{Ti}-\mathrm{C}$ 系については, SGTE Solution Database ver. 2 (1994)の熱力学データ ${ }^{9-17)}$ を用いた.

\section{3. 計 算 結 果}

本研究ではクラッド材の組み合わせとして，(1)普通鋼/
Global conditions :

Pressure $=101325 \mathrm{~Pa}$

Simulation time $=0,10^{3}, 10^{5}, 10^{7}, 10^{9}, 10^{10} \mathrm{~s}$

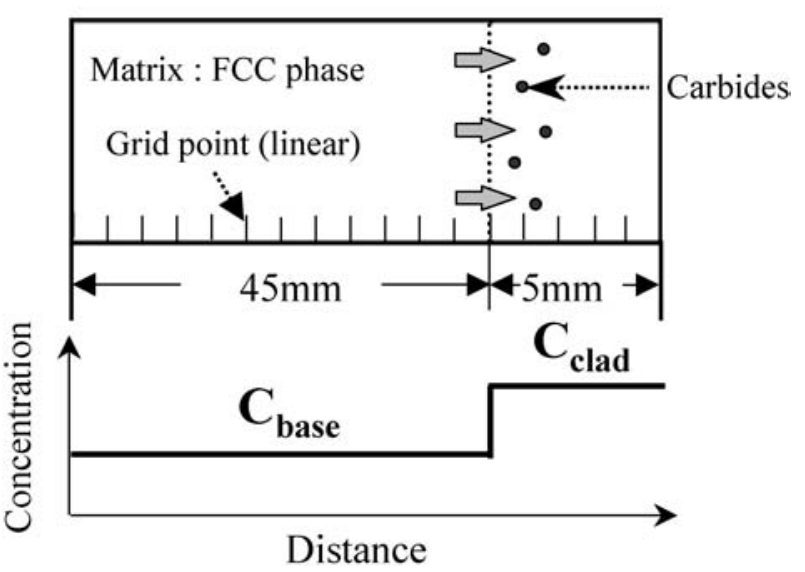

Fig. 2 Calculation conditions in the simulation of this work.

$13 \mathrm{Cr}$ 系ステンレス鋼, (2)普通鋼/18-8 系ステンレス鋼, (3) 普通鋼 $/ \mathrm{Ti}$ 添加 18-8 系ステンレス鋼の 3 種類を想定し, 界 面近傍での拡散挙動の解析を行った。計算に際しては, Fig. 2 のようなセルとよばれる 2 次元平面領域を考え，この中に 母相 (FCC)を配置した，セル中には界面を置かず，母材と 合せ材を区別するために Fig. 2 下部に示したような階段状 の初期濃度プロファイルを設定した．拡散挙動の解析点であ る計算グリッドは，セル中に等間隔に置いた。計算条件は， 圧力 $101325 \mathrm{~Pa}$ ，シミュレーション時間は最大 $10^{10}$ 秒まで とした。 またいずれの組み合わせでも，Thermo-Calcによ る平衡計算により，時間の経過と共に C 原子が母材から合 せ材側に拡散するように，Cの化学ポテンシャル勾配を考慮 して合金組成を決定した。

\section{1 普通鋼 $/ 13 \mathrm{Cr}$ 系ステンレス鋼における拡散挙動}

母材に厚さ $0.045 \mathrm{~m}$ の $\mathrm{Fe}-0.3$ mass $\% \mathrm{Si}-0.05$ mass $\% \mathrm{C}$ 系 普通鋼，合せ材に厚さ $0.005 \mathrm{~m}$ の $\mathrm{Fe}-13$ mass $\% \mathrm{Cr}-0.10$ mass $\% \mathrm{C}$ 系ステンレス鋼を選び, $1173 \mathrm{~K}$ で拡散処理のシミ ュレーションを行った． Fe- 0.3 mass $\% \mathrm{Si}-\mathrm{C}$ 系計算状態図を Fig. 3 (a) , Fe-13 mass \% Cr-C 系計算状態図を Fig. 3(b)に 示した. Fig. 3(a)の 0.05 mass\%Cで計算された C の化学ポ テンシャルは $-31963 \mathrm{~J} / \mathrm{mol}$ であり，組織はオーステナイト (FCC) とフェライト (BCC)の 2 相であった. 一方, Fig. 3(b)の状態図に抢ける 0.10 mass \% C では，化学ポテンシャ ルはー41809 J/mol，組織はオーステナイト (FCC) 単相であ った.ただし化学ポテンシャルは, 熱処理温度と同じ 1173 $\mathrm{K}$ における黒鉛を基準にとった。計算に際しては，母相を FCC 相とし，母材の BCC 相は FCC 相中に均一に分散させ た、計算グリッドは等間隔に 100 点置いた。このような化 学ポテンシャル勾配下では, 合金中の C 濃度は合せ材側の 方が高いにもかかわらず，実際には $\mathrm{C}$ 原子が母材から合せ 材側に拡散し，その結果表面層に $\mathrm{Cr}_{23} \mathrm{C}_{6}$ が析出することが 予想される。

計算により得られた $\mathrm{C}$ 濃度プロファイルを, $t=0,10^{3}$, 


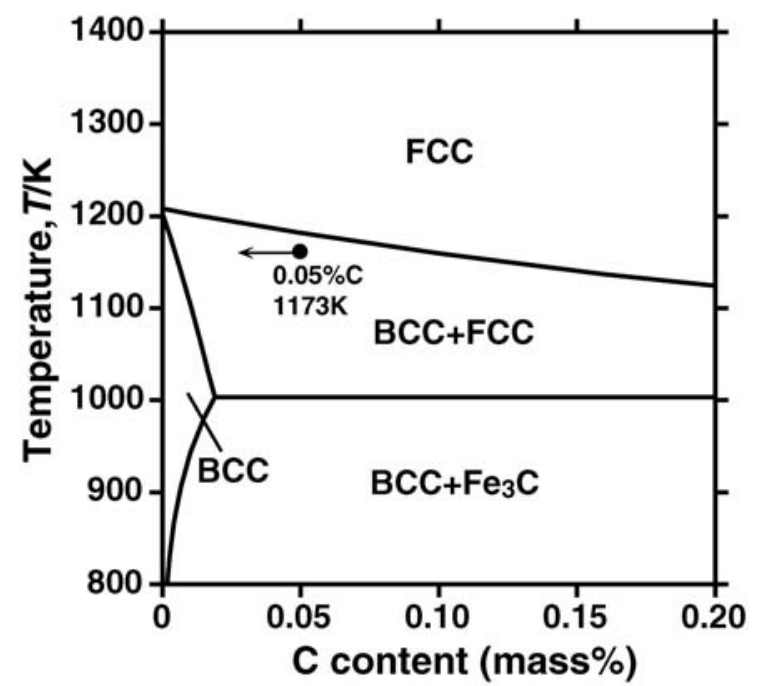

(a)

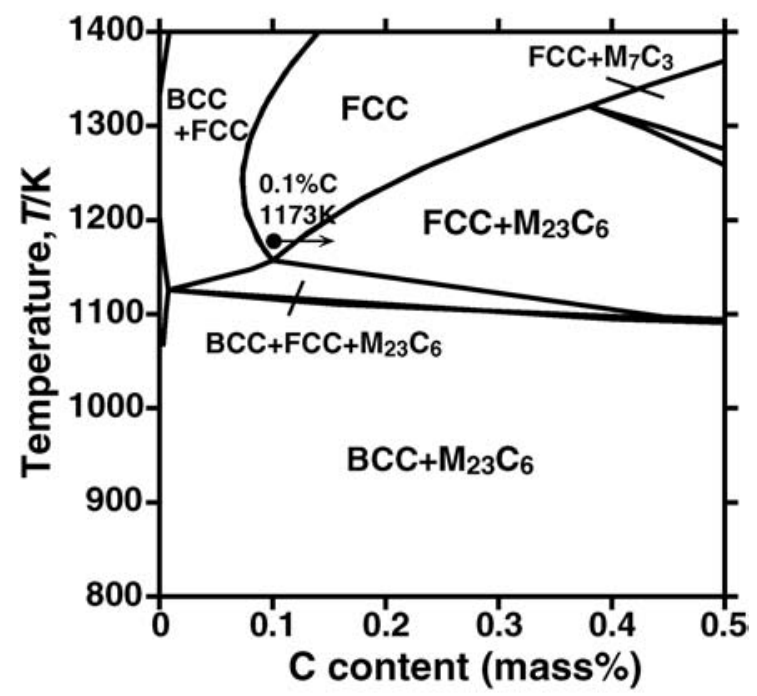

(b)

Fig. 3 Calculated phase diagrams of the (a) $\mathrm{Fe}-\mathrm{Si}-\mathrm{C}$ system and (b) $\mathrm{Fe}-\mathrm{Cr}-\mathrm{C}$ system.

$10^{5}, 10^{7}, 10^{9}$ 秒について Fig. 4 に示した. この結果より, 時 間の経過と共にC が低濃度の母材から高濃度の合せ材へ拡 散することがわかる. また, 表面層への浸炭に伴って母材中 の C 濃度が低下する様子も観察される。このような特異な 拡散現象は, Darken ${ }^{18)}$ により見出された up-hill diffusion として知られているものであり, オーステナイト中での C 原子と $\mathrm{Cr}$ 原子の強い引力的相互作用が巨視的に現れたもの として理解される. Fig. 5 に示した $\mathrm{Cr}_{23} \mathrm{C}_{6}$ 相の相分率の時 間変化からわかるように, 表面層への浸炭が進むにつれて界 面から $\mathrm{Cr}_{23} \mathrm{C}_{6}$ 相が析出する挙動が確認された. 一方, この ような $\mathrm{C}$ 濃度の変化に伴う $\mathrm{Cr}$ と $\mathrm{Si}$ の濃度プロファイルの 時間変化を Fig. 6(a) と Fig. 6(b)にそれぞれ示した。いずれ の元素に颃いても, 接合界面のごく限られた領域での濃度变 化しか観察されなかった。

\section{2 普通鋼/18-8 系ステンレス鋼における拡散挙動}

母材に厚さ $0.045 \mathrm{~m}$ の $\mathrm{Fe}-0.20 \% \mathrm{Mn}-0.03 \% \mathrm{Si}-0.027 \%$

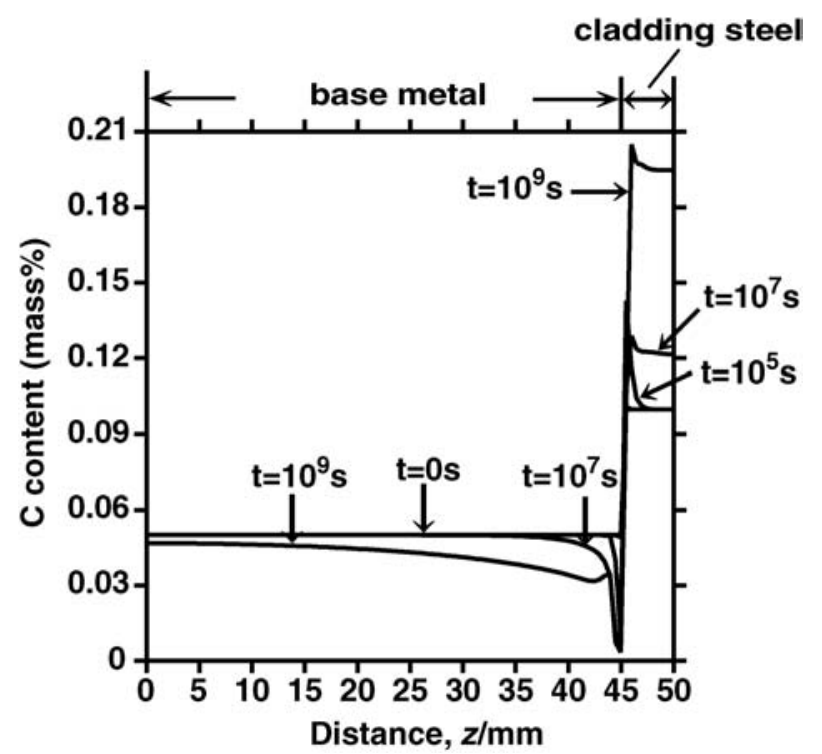

Fig. 4 Calculated $\mathrm{C}$-concentration profiles after $0,10^{3}, 10^{5}$, $10^{7}$ and $10^{9} \mathrm{~s}$ at $1173 \mathrm{~K}$.

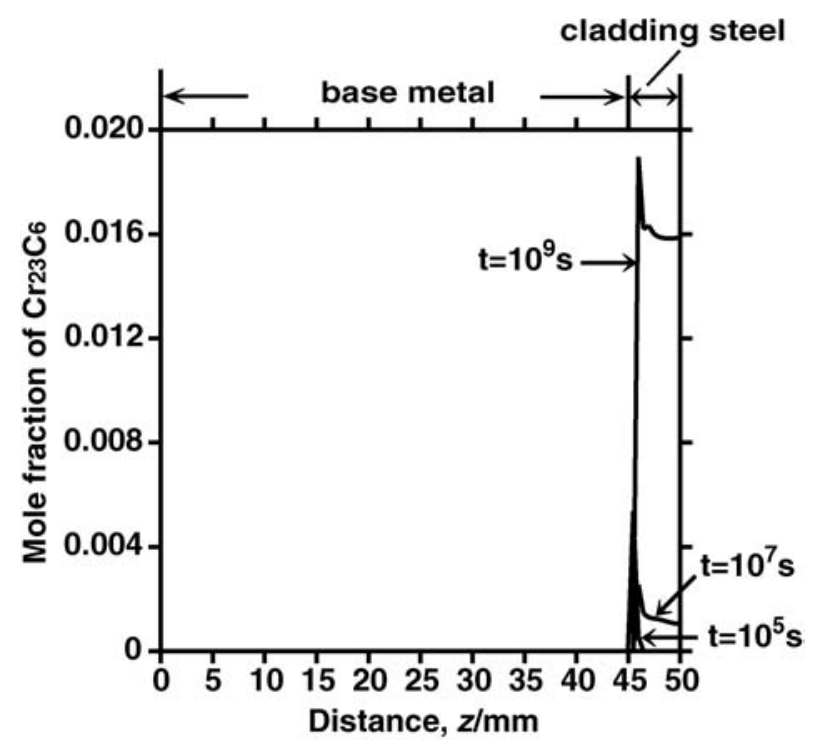

Fig. 5 Calculated mole fraction of $\mathrm{Cr}_{23} \mathrm{C}_{6}$ after $0,10^{3}, 10^{5}, 10^{7}$ and $10^{9} \mathrm{~s}$ at $1173 \mathrm{~K}$.

$\mathrm{Al}-0.046 \% \mathrm{C}$ 普通鋼, 合せ材に厚さ $0.005 \mathrm{~m}$ の $\mathrm{Fe}-18 \% \mathrm{Cr}-$ $8 \% \mathrm{Ni}-0.065 \% \mathrm{C}$ ステンレス鋼を選び， $1200 \mathrm{~K}$ で拡散処理の シミュレーションを行った。 $\mathrm{Fe}-0.20 \% \mathrm{Mn}-0.03 \% \mathrm{Si}-$ $0.027 \% \mathrm{Al}-\mathrm{C}$ 系計算状態図を Fig. 7 (a), $\mathrm{Fe}-18 \% \mathrm{Cr}-8 \% \mathrm{Ni}-$ C 系計算状態図を Fig. 7 (b)に示した． 3.1 節の計算と同様 に, 母材から合せ材へ C 原子の拡散が生ずるように両者の C 濃度を選び, 母材側を $0.046 \%$ (化学ポテンシャル值 $-37644 \mathrm{~J} / \mathrm{mol}$ ), 合せ材側を $0.06 \%$ (化学ポテンシャル值 $-48857 \mathrm{~J} / \mathrm{mol}$ ) に決定した。初期組織はいずれもオーステ ナイト $(\mathrm{FCC})$ 単相であった。計算に際し，グリッドは等間 隔に合計 100 点置いた. Fig. 7 (b) より, C 原子の拡散に伴 って合せ材側では $\mathrm{M}_{23} \mathrm{C}_{6}(\mathrm{M}$ は $\mathrm{Cr}, \mathrm{Ni})$ の析出が予想される.

計算により得られた C 濃度プロファイルを, $t=0,10^{3}$, $10^{5}, 10^{7}, 10^{9}$ 秒について Fig. 8 に示した. また合せ材中に析 


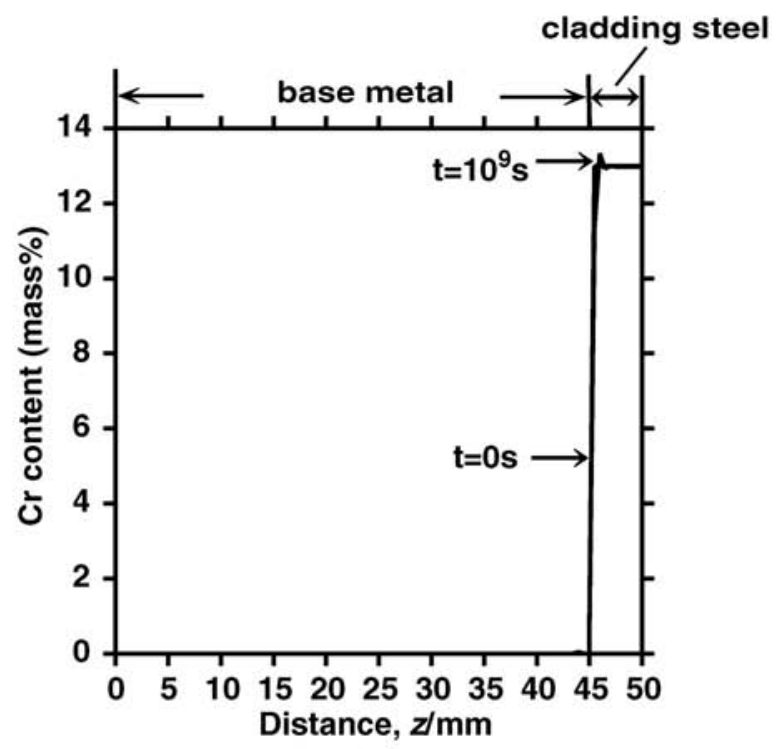

(a)

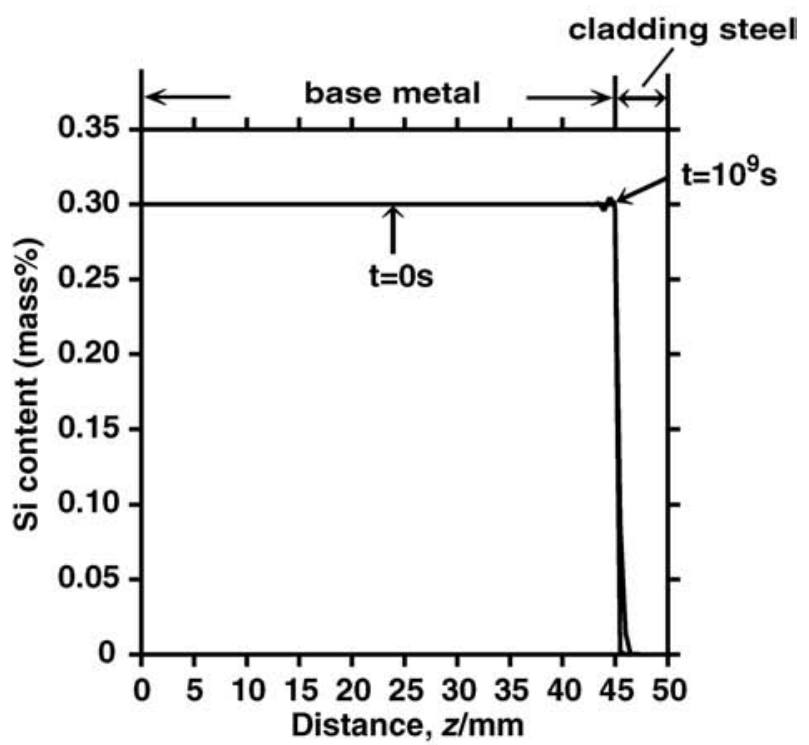

(b)

Fig. 6 Calculated (a) Cr-concentration profile and (b) $\mathrm{Si}^{-}$ concentration profile after $0,10^{3}, 10^{5}, 10^{7}$ and $10^{9} \mathrm{~s}$ at $1173 \mathrm{~K}$.

出する $\mathrm{M}_{23} \mathrm{C}_{6}$ 相の相分率の時間変化を Fig. 9 に示した. 3.1 節の計算と同様に, 時間の経過と共に低 C 濃度の母材から 高 $\mathrm{C}$ 濃度の合せ材へ $\mathrm{C}$ 原子の拡散が生じ, 合せ材中に $\mathrm{M}_{23} \mathrm{C}_{6}$ が析出することがこれらの図よりわかる.

\section{3 普通鋼/ $\mathrm{Ti}$ 添加 18-8 系ステンレス鋼における拡散挙動}

3.2 節のクラッド鋼の組み合わせを基本として, 合せ材に $0.03 \% \mathrm{Ti}$ を添加した場合について $1350 \mathrm{~K}$ で拡散処理のシミ ュレーションを行った. $\mathrm{Fe}-0.20 \% \mathrm{Mn}-0.03 \% \mathrm{Si}-0.027 \% \mathrm{Al}-$ C 系状態図を Fig. 10 (a), Fe-18\% Cr-8\% Ni-0.03\% Ti-C 系 状態図をFig. 10 (b)に示した。合金のC 濃度は, 母材側を $0.046 \%$ (化学ポテンシャル值 $-47673 \mathrm{~J} / \mathrm{mol}$ ), 合せ材側を 0.065\%(化学ポテンシャル值 $-57449 \mathrm{~J} / \mathrm{mol}$ ) とした。初期組 織はいずれもオーステナイト (FCC) 単相であった。計算に 際し、グリッドは等間隔に合計 150 点置いた. Fig. 10(b)よ

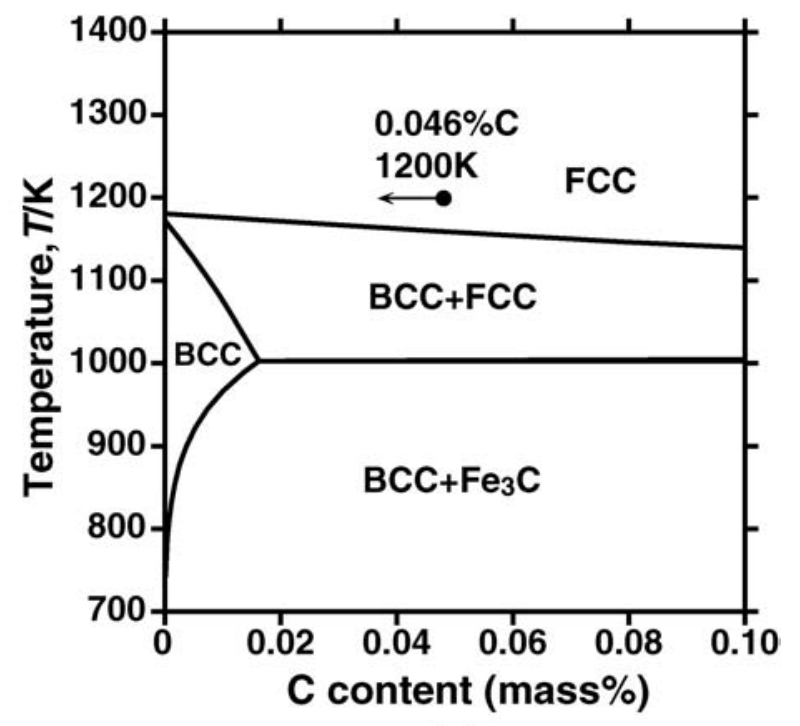

(a)

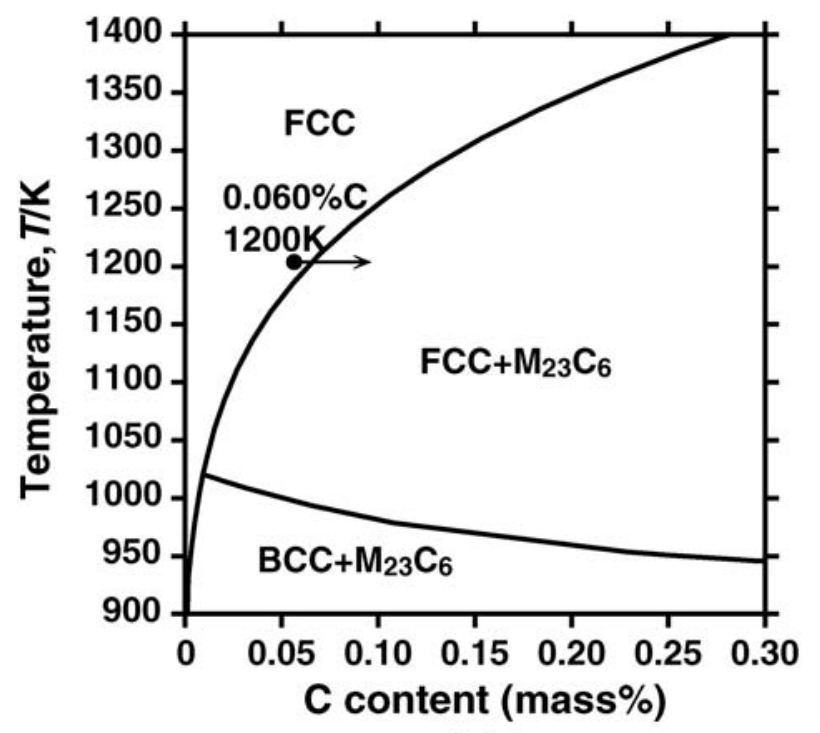

(b)

Fig. 7 Calculated phase diagrams of the (a) $\mathrm{Fe}-\mathrm{Mn}-\mathrm{Si}-\mathrm{Al}-\mathrm{C}$ system and (b) $\mathrm{Fe}-\mathrm{Cr}-\mathrm{Ni}-\mathrm{C}$ system.

り, C 原子の拡散に伴って合せ材側では $\mathrm{TiC}$ の析出が予想 される。

計算により得られた C 濃度プロファイルを, $t=0,10^{3}$, $10^{5}, 10^{7}, 10^{9}, 10^{10}$ 秒について Fig. 11 に示した. Ti を添加し ていない 3.2 節の計算結果に比較して, 合せ材側の C 濃度 は低いが，これはこの領域に析出する $\mathrm{TiC} の$ 固溶度が $\mathrm{M}_{23} \mathrm{C}_{6}$ のそれに比べて低いことに対応している. また合せ材 中に析出する $\mathrm{TiC}$ 相の相分率の時間変化を Fig. 12 に示し た. 時間の経過と共に, $\mathrm{TiC} の$ 析出領域が表面に近い領域に 移動していることがわかる.これは Fig. 13 の Ti の濃度プ ロファィルからも明らかなように, Ti 原子の母材への拡散 が生じていることが原因である.このような溶質原子の拡散 は, $\mathrm{Cr}$ など他の元素についても生じるが，これは拡散処理 温度が 3.1 節および 3.2 節の場合よりも高温であるためであ ると考えられる. このため $t=10^{10}$ 秒以上の長時間加熱で は，いったん析出した TiCが合せ材に再固溶する。 


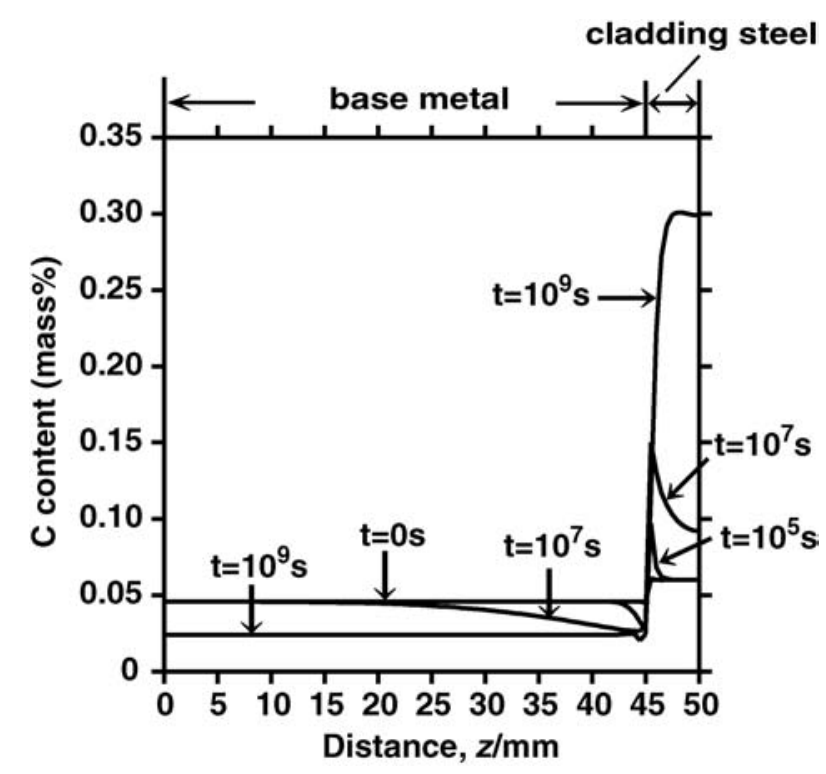

Fig. 8 Calculated C-concentration profiles after $0,10^{3}, 10^{5}$, $10^{7}$ and $10^{9} \mathrm{~s}$ at $1200 \mathrm{~K}$.

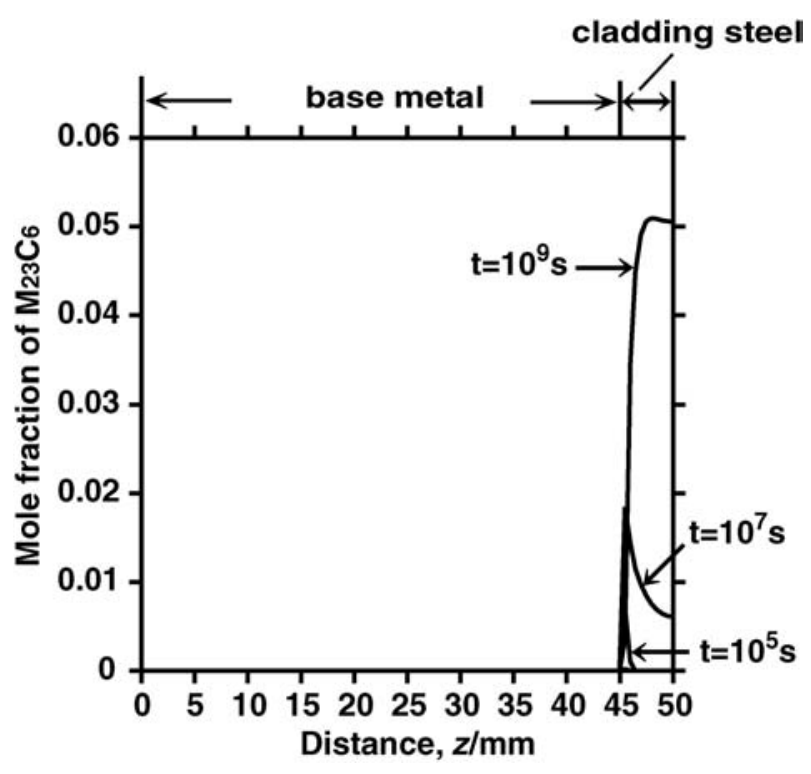

Fig. 9 Calculated mole fraction of $\mathrm{M}_{23} \mathrm{C}_{6}$ after $0,10^{3}, 10^{5}, 10^{7}$ and $10^{9} \mathrm{~s}$ at $1200 \mathrm{~K}$.

\section{4. 結言}

本研究では, 鉄系クラッド材の組織制御に関する基礎的側 面を明らかにすることを目的として，クラッド界面に抢ける $\mathrm{C}$ 原子の拡散挙動を拡散律速型変態計算ソフトウェア DICTRA により検討し, 以下のような結果を得た.

(1) 普通鋼 $/ 13 \mathrm{Cr}$ 系ステンレス鋼, 普通鋼/18-8 系ステン レス鋼, 普通鋼/ $\mathrm{Ti}$ 添加 18-8 系ステンレス鋼の 3 種類のク ラッド鋼に対して，時間の経過と共にC 原子が母材から合 せ材側に拡散するようにCの化学ポテンシャル勾配を考慮 して合金組成を決定した。これらに対し，1173 K, $1200 \mathrm{~K}$ あるいは $1350 \mathrm{~K}$ における拡散処理のシミュレーションを行

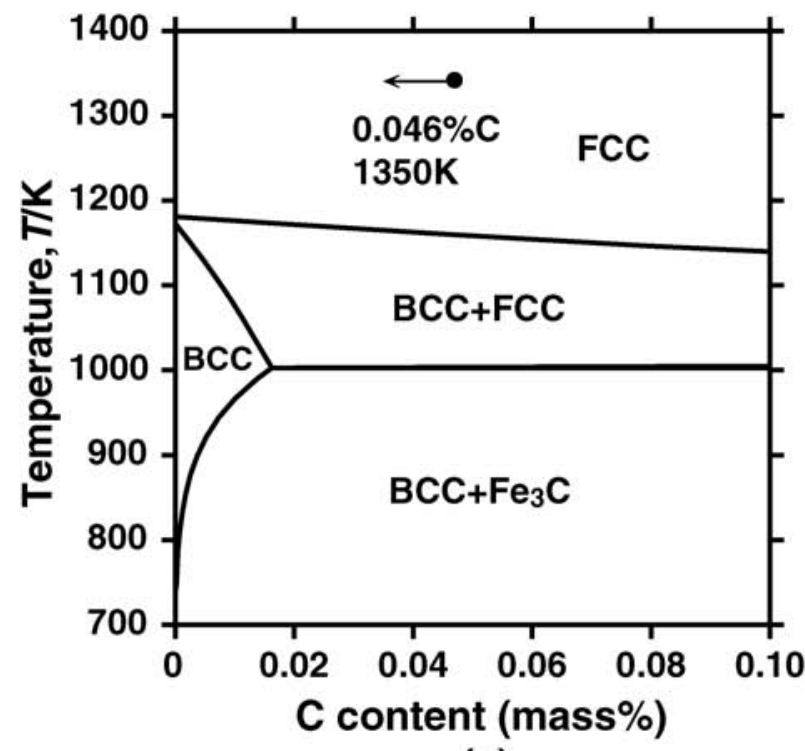

(a)

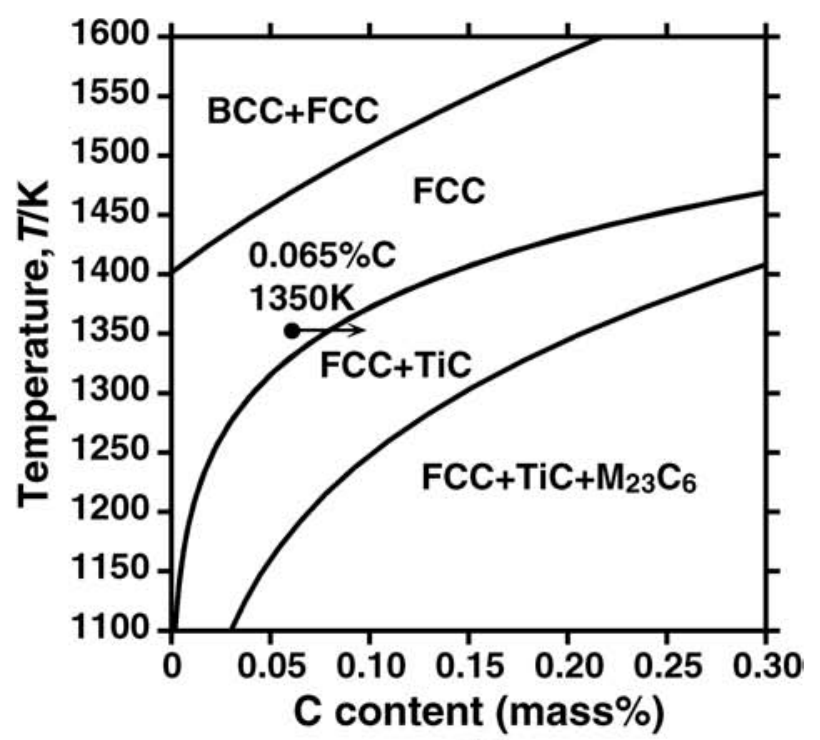

(b)

Fig. 10 Calculated phase diagrams of the (a) Fe-Mn-Si-Al-C system and (b) $\mathrm{Fe}-\mathrm{Cr}-\mathrm{Ni}-\mathrm{Ti}-\mathrm{C}$ system.

ったところ, 高 Cである合せ材が母材の C 原子を吸収し, 表面層がより高い C 組成となるような up-hill diffusion が生 ずることがわかった。

(2) 合せ材への C 原子の濃化に伴って, 界面近傍に $\mathrm{M}_{23}$ $\mathrm{C}_{6}$ や $\mathrm{TiC}$ が析出することがわかった。このような $\mathrm{C}$ 濃度の 変化に伴う溶質元素の濃度は, $1173 \mathrm{~K}$ と $1200 \mathrm{~K}$ では接合 界面のごく限られた領域での変化しか観察されなかった。一 方, 熱処理温度が $1350 \mathrm{~K}$ では, 溶質元素は母材へかなり拡 散し, いったん析出した TiC が合せ材に再固溶することが わかった。

本研究の遂行にあたっては, 新日本製鐵秼鉄鋼研究所, 赤松 聡氏より有益な御助言をいただきました。 また本研究 の一部は, (独) 日本学術振興会科学研究費補助金 (基盤研究 (C) (2)) (14550720)により行われています. 


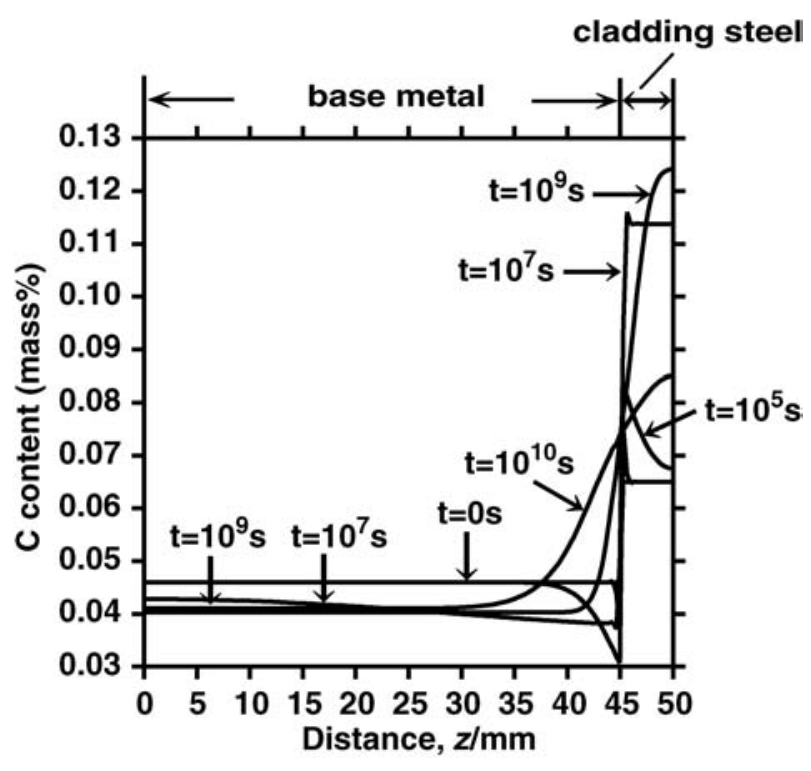

Fig. 11 Calculated C-concentration profiles after $0,10^{3}, 10^{5}$, $10^{7}, 10^{9}$ and $10^{10} \mathrm{~s}$ at $1350 \mathrm{~K}$.

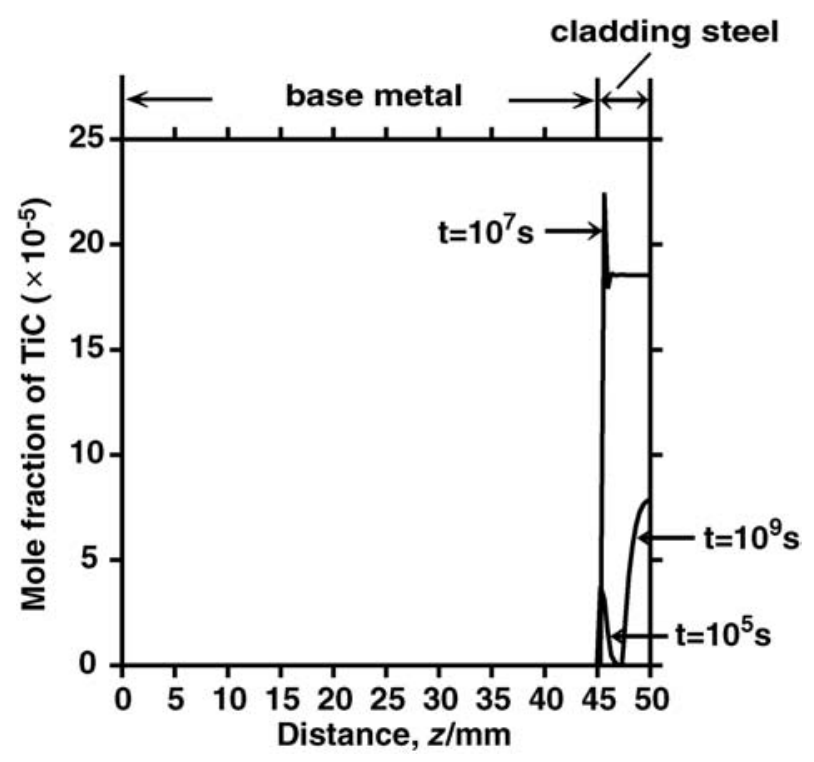

Fig. 12 Calculated mole fraction of TiC after $0,10^{3}, 10^{5}, 10^{7}$, $10^{9}$ and $10^{10} \mathrm{~s}$ at $1350 \mathrm{~K}$.

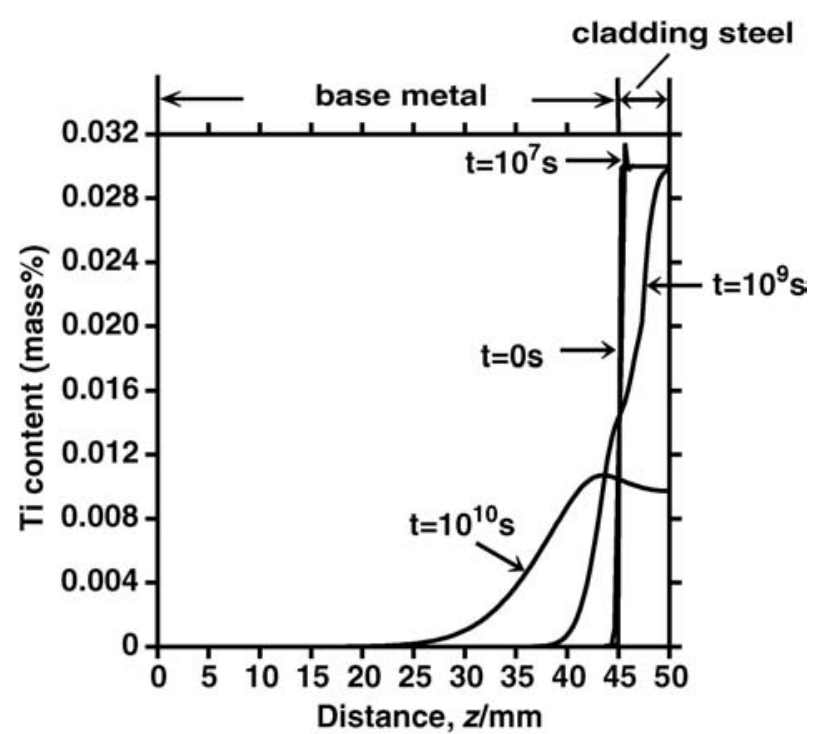

Fig. 13 Calculated Ti-concentration profiles after $0,10^{3}, 10^{5}$, $10^{7}, 10^{9}$ and $10^{10} \mathrm{~s}$ at $1350 \mathrm{~K}$.

文献

1) S. Akamatsu, M. Suehiro and T. Senuma: Proceedings of CALPHAD, XXIV (1995) 47.

2) J.-O. Andersson, T. Helander, L. Höglund, P. Shi and B. Sundman: CALPHAD 26 (2002) 273-312.

3) M. Suehiro and J. Ågren: Materia Japan 38(1999) 629-632.

4) M. Onishi, Y. Wakamatsu and T. Shimozaki: Materia Japan 33(1994) 940-947.

5) P. G. Shewmon: Diffusion in solids, (McGrow-Hill, New York, 1963).

6) A. Borgenstam, A. Engstrom, L. Höglund and J. Ågren: J. Phase Equilib. 21 (3) (2000) 269-280.

7) B. Jönsson: Scand. J. Metall. 23 (1994) 201-208.

8) B. Jönsson: Scand. J. Metall. 24(1995) 21-27.

9) P. Gustafson: Scand. J. Metall. 14 (1985) 259-267.

10) J.-O. Andersson and B. Sundman: CALPHAD 11(1987) 83-92.

11) J.-O. Andersson: Met. Trans. A 19A(1988) 627-636.

12) W. Huang: Metall. Trans. 21A(1990) 2115-2123.

13) W. Huang: CALPHAD 13 (1989) 243-252.

14) D. Ludecke: Z. Metallkde. 77 (1986) 278-283.

15) J. Lacaze and B. Sundman: Met. Trans. A 22A(1991) 22112223.

16) A. Gabriel, P. Gustafson and I. Ansara: CALPHAD 11(1987) 203-218.

17) A. Forsberg and J. Ågren: TRITA-MAC 483(1992).

18) L. S. Darken: Trans. AIME 180(1949) 430-438. 